\title{
On media monitoring - the Media for Democracy Monitor (MDM)
}

\author{
Trappel, J ; Maniglio, T
}

\begin{abstract}
Do the mass media deliver what contemporary democracies require? This fundamental research question has been discussed for many decades and the body of literature is firmly rooted in the debate following from the Hutchins Commission 1947. In more recent years, monitoring of the relations between democracy and the mass media has concentrated on new or democracies in transition. Fewer monitoring efforts have been undertaken in mature democracies. The following text develops a social science based monitoring instrument for established democracies, the Media for Democracy Monitor (MDM). It has been developed at the University of Zurich and tested in five European countries (Germany, the Netherlands, Lithuania, Portugal, and Switzerland).
\end{abstract}

DOI: https://doi.org/10.1515/COMM.2009.012

Posted at the Zurich Open Repository and Archive, University of Zurich ZORA URL: https://doi.org/10.5167/uzh-25237

Journal Article

Published Version

Originally published at:

Trappel, J; Maniglio, T (2009). On media monitoring - the Media for Democracy Monitor (MDM). Communications: The European Journal of Communication Research, 34(2):169-201.

DOI: https://doi.org/10.1515/COMM.2009.012 


\title{
On media monitoring - the Media for Democracy Monitor (MDM)
}

\author{
JOSEF TRAPPEL and TANJA MANIGLIO \\ E-mails: j.trappel@ipmz.uzh.ch; t.maniglio@ipmz.uzh.ch.
}

\begin{abstract}
Do the mass media deliver what contemporary democracies require? This fundamental research question has been discussed for many decades and the body of literature is firmly rooted in the debate following from the Hutchins Commission 1947. In more recent years, monitoring of the relations between democracy and the mass media has concentrated on new or democracies in transition. Fewer monitoring efforts have been undertaken in mature democracies. The following text develops a social science based monitoring instrument for established democracies, the Media for Democracy Monitor (MDM). It has been developed at the University of Zurich and tested in five European countries (Germany, the Netherlands, Lithuania, Portugal, and Switzerland).
\end{abstract}

Keywords: media monitoring, democracy, mass media

\section{Introduction}

Modern democracy and the mass media are intrinsically related. In modern democracies the mass media are the link between those who govern and those who are governed. Mass media need democracy because it is the only form of government that respects freedom of speech, expression, and information, and the independence of the media from the government (Strömbäck, 2005: 332). Political ideas and initiatives, in turn, are disseminated among citizens by the mass media and individual opinion formation and voting are largely based on political information provided by mass media.

From a normative perspective, the media have three specific democratic functions to carry out: (1) safeguarding the flow of information; (2) providing a forum for public discussion about diverse, often conflict- 
ing political ideas; and (3) acting as a public watchdog against the abuse of power (Strömbäck, 2005: 332).

Fulfilling these functions is not only of particular importance in socalled new or restored democracies where media systems suffered from oppression, corruption, or the effects of war and underdevelopment. These functions are also of paramount importance in so-called established or mature democracies. While the former group of countries has been subjected to various efforts to monitor the performance of the media, the latter has partially slipped out of view.

It often goes unquestioned that the media in mature democracies fulfill their role for democracy in the best possible way. However, there are some doubts: It can be argued that in such states the mass media's actual contribution to democracy barely meets the normative demands described above. This might be due to the interrelated processes of growing media commercialization and mediatization of politics. Market-driven reforms have indeed stimulated commercialization and fierce media competition. Political actors and organizations, which depend on the media to communicate with the electorate, have, in turn, been forced to adapt to the new media logic.

In any democratic system it is thus important to analyze if and how media actually serve the needs of democracy - as well as if and how the media fail to meet their democratic functions. In this regard, media monitoring can be of "strategic importance," as Kaarle Nordenstreng highlights:

"You cannot improve the media through legal and economic measures except in marginal ways, but you can do a lot by maintaining a culture of constant, ruthless criticism of media content and media monitoring, which involves professionals, academics, and the general public"

(2001: 63).

There is a substantial number of media monitoring institutions. However, most of these instruments focus on democracies in transition and do not provide much insight regarding the performance of the media in mature democracies. We thus identify a need for a monitoring instrument that measures media performance in a more sophisticated and social science based way.

This paper begins with a discussion of the theoretical considerations and concepts regarding the relationship between media and democracy. It draws from the main schools of thought on modern democracy, explaining what services they require from the media and what criteria they establish for the measurement of media performance. In the follow- 
ing section a newly developed instrument for media monitoring is presented - the Media for Democracy Monitor (MDM). The MDM has been applied in five selected European democracies in a pilot study.

\section{Theoretical considerations}

In order to understand the relationship between media and democracy, we first must ask: What does democracy theoretically require from media? Consequently, in order to obtain the relevant criteria for the evaluation of media performance it is essential to distinguish between different concepts of democracy, for these concepts determine the requirements: "At a time when most people rely on media for information, and when political actors have to adapt to media logic it is reasonable to expect that they [democratic concepts] also pose different normative obligations upon media" (Strömbäck, 2005: 333). However, democracy is not onedimensional. In principle, there are as many concepts of democracy as there are democratic countries. Several views about what characterizes democracy give way to a multitude of concepts of democracy. Selections from recent overviews of democratic theory (Strömbäck, 2005; Held, 2006) draw a difference between several basic concepts of democracy that can be classified on a continuum from minimal to maximal variants: 'Elitist democracy' is based on a minimalist conception; 'participatory democracy' is based on a mid-range concept; and 'deliberative democracy' is based on a broader understanding of democracy ${ }^{1}$.

\section{Concepts of democracy}

From the extensive body of literature on the various models of democracy we chose three prototypes: the elite or minimalist concept of democracy; the participatory concept; and the deliberative concept of democracy. This choice represents contemporary scholarly theories of democracy.

The minimalist perspective assumes that every political system is ruled by political elites capable of making public decisions and protecting individual liberty. The broader public has neither adequate ability to nor interest in governing itself. Citizens nevertheless represent the final step that elects the representatives that will govern for a predefined period of time. This view thus assumes active political elites on the one hand and reacting citizens on the other. The concept is based on ideas of classical republicanism (Held, 2006: 32-55), the classical liberal model of democracy (Fenske et al., 1994), and its more recent developments in the form of the elite (Held, 2006: 125-157) or pluralist models of democracy (Schmidt, 2000: 226-239) ${ }^{2}$. According to elite democracy, the basic 
requirement of the media is to provide citizens with reliable information. In order to choose between competing political elites, people need information and knowledge about political issues and actors.

Participatory democracy understands democracy as a value-laden system where a strong ethos of citizen involvement, political equality, and tolerance play crucial roles. Democracy is sustained by dedicated citizens: "The more people are politically interested, the more they engage in associations and civic organizations, the more they vote, the more they develop attitudes and norms of generalized reciprocity, the better" (Strömbäck, 2005: 336). Therefore, democracy can never be built or sustained by elected skilled elites; it must be built and sustained by the actions of a large number of people. Citizens act directly as a collective and aim for the common good. This concept of democracy can be traced back to classical Athenian democracy (Held, 2006: 11-28), to the developmental form of classical republicanism (Held, 2006: 43-55) and it implies ideas of direct democracy (Held, 2006: 96-122; Schmidt, 2000: $165-174)^{3}$. The participatory view stipulates that media let citizens set the agenda for their news coverage. Moreover, media should frame politics as open for everyone in order to mobilize people's interest, engagement, and participation in public life.

The third concept of democracy discussed here, deliberative democracy, can be understood as an extension of participatory democracy. The core idea of the deliberative concept of democracy is " $[t]$ hat the notion includes collective decision-making with the participation of all who will be affected by the decision or their representatives: this is the democratic part. Also, all agree that it includes decision-making by means of arguments offered by and to participants who are committed to the values of rationality and impartiality: this is the deliberative part" (Elster, 1998: 8). Citizens need opportunities to deal more profoundly with political issues in deliberative ways. Ideally, deliberative discussions should be a part of daily life and decision-making on all levels in society. Over the past few years, the discussion on deliberative democracy has attracted increased interest (Elster, 1998; Gutmann and Thompson, 1996; Habermas, 1992). Like participatory democracy, deliberative democracy calls on the media to mobilize people to participate in the political process. What this concept adds is an emphasis on political discussions and the importance of their deliberative nature. The active participation of the media is therefore an essential element. In other words: Media should provide factual information, as well as actively foster political discussions as "fair-minded participants" (Merritt, 1998).

None of these non-exclusive contemporary democracy concepts are entirely unambiguous and, in reality, democratic states may exhibit elements from each of these concepts to varying degrees. This includes the 
implications for media regarding the different normative expectations on politicians and citizens briefly referred to above. Scholarly works on political theory, however, tend to concentrate on democracy without focusing on the media (Schudson, 1996: 205). The importance of the media as democratic institutions and their contributions to democracy are often taken for granted and therefore have remained more or less unexplored (Voltmer, 1999: 14).

\section{Democracy theories in media and communication research}

While the big questions of democratic theory rarely lead researchers to the media, some media and communication scholars, by contrast, are considering the central importance of the media for democracy. They see media freedom as well as the accountability of the media as indispensable elements of a democratic societal order. Media therefore must remain separate from the government and other powers of society, such as vested economic interests, and should be held accountable to society as a whole.

The initial theoretical work on this topic is a study published more than fifty years ago (Siebert, Peterson and Schramm, 1956). This study was a by-product of the American Commission on Freedom of the Press (Hutchins Commission, 1947) and became a baseline for describing how different media systems operate around the world. The text proposes that media tend to be a reflection of the society in which they are located and therefore provide access to various points of view. Its ideas belong to the core of libertarian theory and suit the model of a responsible free press in a modern democracy, labeled the "social responsibility" model. Freedom of the press is related to the view of a free marketplace of ideas and of self-imposed responsibility. However, the scholarly weight of the text and its ideological basis were widely criticized not least because of its oversimplified framing of history, its analytical inadequacy, and its U.S.-based research (e.g., Nerone, 1995; McQuail, 1994; Hallin and Mancini, 2004).

More recently, various authors have found alternative routes to take other realities and other models of the functioning of the media in a democratic society into account. Picard (1985) defines a democratic framework for understanding the changing nature of media economics and government-press relations in terms of Western models, termed the "democratic socialist" model. The text offers proposals for achieving both a democratically functioning press (even through collective ownership) to assure independence from special interests and broader public intervention to provide access and diversity of opinion. "Under the democratic socialist view, media can be truly democratic only if they are removed from the private sector, spared the effects of economic competi- 
tion, freed from undue restraints and pressures - whatever the source and induced to provide the capacity for citizens to communicate effectively with other citizens" (Picard, 1985: 35).

Raboy and Bruck (1989) distinguish between three conceptions of democracy by looking at that which they struggle against. "Liberal democracy" fights against censorship and all forms of prohibition; "social democracy" opposes economic domination; and "cultural or communication democracy" fights against "spectacularization" (which today we might label as "scandalization").

According to Schudson (2003), three models determine how media are governed: the "market," the "trustee," and the "advocacy" model. The market-based model follows the laws of the marketplace and does not specifically posit any normative links to media. The trustee model implies that media protect the citizen's interests, for example, by focusing on regulators or legal requirements. The advocacy model calls for the media to serve the public by arguing a consistent and coherent point of view, with the aim of newsgathering being to advance a political or social movement. Another classification has been provided by Hallin and Mancini (2004) suggesting three analytical-descriptive concepts of modern democracies: the "North/Central European or democratic corporatist" (citizen interest and media independence is guaranteed by government intervention); the "Mediterranean or polarized pluralist" (the structure of political ideology in a society determines media partisanship); and the "North Atlantic or liberal" (market-based) model. This framework serves first of all the comparative study of Western media systems, as understood within their political and historical contexts.

McQuail (2005) offers a normative model encompassing four prototypes: the "market," the "public interest," the "professional," and the "alternative media" models.

C. Edwin Baker (2006) distinguishes four different concepts of democracy in terms of the requirements for the media. For elite democracy, the greatest importance of the media lies in providing information and in its activity during elections. Between elections, media should serve as the watchdogs over the state and the current administration. Republican democracies focus on the public good, with the media required to objectively take all relevant events and societal developments into account. Liberal-pluralist democracies are based on the representation of different voices in society and media play an important role in making them heard. Finally, complex democracies are built on processes of deliberation. Media should encourage and empower different groups in society to express themselves and advocate for their causes. Baker's work refers to many other earlier works in the realm of democracy and media, such as Webster (1999), Curran (2000), and Dahlgren (2001). 
Kaarle Nordenstreng (2006) describes four different concepts of democracy. Pluralist democracies concentrate on individual freedom, consider market forces as engines of welfare, and allow media a maximum amount of freedom. Administrative democracies rely on expert bodies that should inform the public about their actions and practices, with the media being instruments to this end. Deliberative democracies rely on the self-consciousness of citizens and require the media to assist citizens in becoming involved in issues of public interest. As a fourth model, Nordenstreng adds direct democracy, where media should provide channels for all voices in society.

The brief review of the literature above illustrates the need to clarify the understanding of the relationship between democracy and media. Media studies have produced various normative theories and innumerable models concerning media and democracy. However, there is no systematic school of thought: While the texts provide us with inferences or indications, they have very few elaborate explanations nor do they provide much empirical evidence. Empirical work is accomplished rather by a number of pragmatic media monitoring institutions. These institutions are united in their belief that media are essential elements for the development of democracy. They use different instruments and methodologies to measure mass media's contribution to the functioning of democracy. Their monitoring instruments, however, share weaknesses in their theoretical foundations (Becker, Vlad and Nusser, 2007). It is therefore our intention to develop an instrument rooted in social science that monitors the performance of the media for contemporary democracies.

\section{The Media for Democracy Monitor (MDM)}

The opportunity to develop an instrument to address our research questions was presented to the project team by a major research program based at the University of Zurich within the multi-annual Swiss National Centre of Competence in Research (NCCR) program called "Democracy in the $21^{\text {st }}$ Century."

Our starting point is to investigate the ability of the media to enable, foster, or even hinder the development of contemporary democracies. We assume that legal frameworks are in line with democratic requirements and that the mass media enjoy freedom from censorship and undue government intervention. This basic assumption does, however, limit the range and number of countries that can be analyzed with our instrument. Nevertheless, this limiting assumption still enables us to take a much more detailed and critical look at mass media organizations. Our research question is not whether the government allows for media freedom: Rather, we investigate whether the mass media make the best use 
of their freedoms and to what degree they contribute to democratic life. Our object of research is therefore not the state and its legal and administrative frameworks, but the mass media organizations themselves.

\section{Root concept of democracy}

Drawing from the wide range of concepts of democracy outlined above, we argue that democracy is always based on three fundamental principles: freedom, equality, and control. These principles originate from the 'Age of Enlightenment' and the great democratic revolutions of the $18^{\text {th }}$ and $19^{\text {th }}$ Centuries. They are the principles that proponents of democracy from all eras and places have struggled for and which have accompanied the development of modern states (Schulz, 2000: 1). The principles are broad and robust and warrant more detailed discussion:

Freedom can be understood as consisting of three types of rights: political, civil, and social (or socioeconomic). Freedom rights are based on the idea of people's freedom to act (e. g., freedom of opinion, freedom of association, freedom of information). In their widest sense, freedom rights should thus be viewed as protecting people's ability to act independently and with self-determination in political, economic, social, and cultural terms. Of central importance for people's freedom is the protection against infringements by the state. "Over time, the list of negative freedom rights has grown and the protection and guarantee of these rights have become one of the minimal conditions for democratic regimes." (Bühlmann, Merkel, and Wessels, 2007: 8). Beyond this protection, conditions must be created to ensure that people are able to develop freely and lead a self-determined life. From this perspective, political liberties are seen as preconditions for citizens to actively influence political decisions. This implies that the government must protect freedom rights (Lauth, 2004: 77).

Equality, understood as political equality, proclaims the equality of all citizens in and before the law and in the political process. Equality thus means equal treatment of all citizens by the state and equal rights to participate in politics - i.e., all citizens' preferences have the same weight in political decisions (Dahl, 2006: 4). According to Bühlmann, Merkel, and Wessels (2007: 7), the meaning of equality can be shown by two important struggles: "On the one hand, the emergence of modern democracies goes hand in hand with the growing demand for equal treatment of all citizens by the government. The constitutional guarantee of equality before the law and of the protection of individual rights is the outcome of this development. On the other hand, the importance of political equality is illustrated by the development of universal suffrage: 
the struggle for equal rights to participate for all people went along with the development of democratic states in the last century."

Control is essential for democracy and its political institutions. This principle demands that citizens control their representatives in the government in order to secure their own freedom and equality: "[I]n a good democracy the citizens themselves have the sovereign power to evaluate whether the government provides liberty and equality according to the rule of law" (Diamond and Morlino, 2004: 4). This also implies that citizens, their organizations, and parties participate and compete to hold elected officials accountable for their policies and actions. Moreover, they monitor the efficiency and fairness of the application of the laws as well as the efficacy of government decisions. Governmental institutions also hold one another accountable before the law and the constitution: "The control of the executive over policies [...] must be subject to democratic control and institutional checks and balances" (Bühlmann, Merkel, and Wessels, 2007: 8).

In sum, we define freedom, equality, and control as the three fundamental principles indispensable to classifying a political system as democratic. These principles are not only normatively but also functionally and structurally linked to each other. Therefore, a "quality democracy" is considered "to be one that provides its citizens a high degree of freedom, political equality, and popular control over public policies and policy-makers through the legitimate and lawful functioning of stable institutions" (Diamond and Morlino, 2004: 3).

\section{Democratic media functions}

In order to evaluate the democratic performance of the mass media we must clarify how the three principles of the root concept relate to communication processes. Various authors have convincingly demonstrated the close connection between the principles and specific functions mass media must perform in modern democracies (e. g., Lauth, 2004; Voltmer, 1999, 2000; Schulz, 2000; Norris, 2000; McQuail, 1992, 1999):

Freedom as a principle in civil society has often been defined in terms of communication rights to hold opinions and to receive and convey information: "Political communication in democracy is connected with the idea of freedom. Freedom of expression and opinion-building as individual basic rights and as institutional guarantees for an independent media system are part of the very core of democracy; they are an element of a democratic order per se" (Sarcinelli, 1995: 241; translation by the authors). In this view, freedom of expression is both a crucial individual right and an indispensable social good. Freedom, according to McQuail (1992: 67) and Schulz (2000: 3), also entails the economic freedom of the 
media to operate in their public role and in their private business capacity.

The media's communication function, which derives from freedom, is the information function. Media can perform this function due to their specific capabilities to collect and process large amounts of information as well as to distribute it to all participants of the political process (Voltmer, 1999: 13).

Equality as a principle must be translated into more specific terms if it is to be applied to the mass media: "[Equality], too, is connected with public communication in less direct, but no less crucial ways" (McQuail, 1992: 67). In relation to communication and political power, it is equality that demands that no special favor be given to power-holders and that access to media should be provided on a fair basis to oppositional or divergent opinions, perspectives, or claims. Equality calls for an absence of discrimination or bias in the amount and kind of access available to channels, on equivalent terms, for all alternative voices, as far as is practicable. Or as McQuail (1992: 67) wrote: "If we suppose there to be a 'right to communicate,' then we also suppose an equal claim for all to hear and be heard."

The media's communication function that follows from equality is what might be called public opinion-making or simply the forum function. Mass media as a forum are expected to represent the full range of political standpoints and to give access to all political actors who aim at addressing the public (Voltmer, 2000: 3).

Control, as a principle in relation to communication and power, assumes that the mass media should act on behalf of the public as a watchdog holding government officials accountable (Norris, 2000: 28). In order to preserve the conditions for the enjoyment of civil rights and political liberties, the mass media should act as an independent, fair, and impartial critic of powerful interests. It should also report on abuses of political and economic power. This implies that mass media should not just be informing in an unfiltered way and without critical analysis of political messages. Some liberal authors consider the watchdog function as even more important than the information function. Kelly and Donway (1990: 70) argue: "We have distinguished two political roles of free press in classical liberalism: the watchdog and the democratic [i.e., information] functions. And we noted that for advocates of limited government, the first is by far the more important [...]. The implication of this priority is that even if, contrary to all the evidence we have cited, the government could use its power effectively to strengthen the democratic [i.e., information] function, it would not be justified in doing so at the cost of the watchdog function" (quoted from Voltmer, 1999: 30). 
The media's communication function, which follows from control, is to act as a watchdog against the abuse of all types of power.

To sum up, the functions the media and communication processes must perform in order to promote the three fundamental democratic principles are to serve as (1) a guardian of the flow of information; (2) a public forum for public discussion of diverse, often conflicting political ideas; and as (3) a public watchdog against the abuse of power in its various forms. Although these functions have been identified separately, they are nevertheless interconnected and overlapping. Based on these three media functions, we will now identify more specific features of the media and their environment that enable them to carry out these functions. This is done in order to better assess the media's performance in contemporary democracy.

\section{Dimensions and criteria of the Media for Democracy Monitor (MDM)}

In order to monitor and evaluate the media's performance in a given society, the democratic principles and corresponding media functions must be translated into more specific democratic features (and variables). These features can be divided into performance criteria and structural conditions. Performance criteria correspond to the actual behavior of media organizations, how they interpret their mission, and how they act in their markets with regard to democratic requirements. Structural conditions are external to media organizations. They are set either by government regulation or through self-organizational instruments by the media sector as a whole. Structural conditions are typically not influenced by individual behavior, while performance criteria are entirely under the control of media organizations.

The relevant features can be identified for different levels of analysis: the macro, meso, and micro levels. The macro level focuses on legal and administrative rules and regulations (such as constitutional guarantees, absence of censorship, etc.), the state of available infrastructures, and the degree of media concentration in relevant markets. The meso level refers to the internal organization of the mass media, their ownership and financing, and the degree of independence from the government and other interests. The micro level takes the output of the mass media, their diversity of genres, and their thematic focal points into consideration. Media consumption refers to modalities of reception of mass media as well as to the changes of reception patterns between media genres (including online media).

Freedom, as the principle which demands that mass media carry out information functions, refers to conditions rather than performance criteria (McQuail, 1992: 69). Accordingly, the legal system under which the 
media operate must guarantee individual communication freedom, i.e., the freedom of access to information, the freedom of expression, and the freedom of distribution of opinion (Lauth, 2004: 334). Freedom requires media access to different sources of information. In addition, journalists are the main beneficiaries of specific legal rights "such as a special right of information vis-à-vis state authorities, a right to refuse to give evidence in trials (in order to protect informants), as well as a protection of editorial offices against confiscation by public prosecutors" (Schulz, 2000: 4). Freedom calls not only for the absence of a legally imposed licensing or censorship mechanism, but also for the granting of a degree of independence from political and economic pressures and autonomy for journalists within media organizations. According to Schulz (2000: 4), "[...] media must neither be owned by the state, nor by political parties or by banks and business groups. And these organizations must not have influence through property shared or governing bodies on the contents or the personnel policy of mass media." Although public service broadcasting models show that government intervention need not be inconsistent with communication freedom, it is essential in cases of state monopolies to carefully examine which objectives are actually pursued and if diversity of the media landscape is guaranteed (Lauth, 2004: 179).

From equality, several performance criteria can be deduced that must be met by the media in order to serve as a public forum and to promote opinion-making. Equality demands a "[...] fair access to channels, on equivalent terms, for all alternative voices that meet relevant criteria" (McQuail, 1992: 71). From this 'communication equality,' the criterion of media diversity can be deduced. Media systems characterized by a high degree of diversity fulfill the function of a public forum where the exchange of arguments and collective deliberation takes place. According to Voltmer (2000: 9), diversity implies partially independent two aspects: diversity of media actors (the quantitative dimension) and diversity of opinions (the content dimension).

Diversity of actors refers to the number of media actors that participate in the political communication process. While quantity is certainly a necessary condition, it does not suffice for media diversity: "A high number of the 'same' would not allow meaningful choices on the part of the citizens. The emphasis is therefore on significant differences between the media [...]" (Voltmer, 2000: 9). In this regard, ownership structure is usually regarded as the most crucial element. Ownership concentration limits competition between media actors and thus reduces diversity. According to Voltmer (2000: 9), "the increasing internationalization of media companies is a severe impediment of transparency and political control of ownership structures." Accordingly, the main goal of formal media regulation is to preserve media diversity by guaranteeing a number 
of media outlets with different ownership. Moreover, diversity is enhanced by different forms of media financing and control: "A system that comprises both forms of formal arrangement provides more possibilities of choice than a monostructural system. Diversity is even higher when each of the structural alternatives consists of more than one actor" (Voltmer, 2000: 10).

Diversity of content refers to the political viewpoints represented and supported by the media: "In the context of democratic opinion building the diversity of opinions is the ultimate dimension of the diversity concept" (Voltmer, 2000: 10). As a structural attribute, content diversity refers to the media's general policy of information processing rather than the actual reporting (McQuail, 1992: $170 \mathrm{ff}$.). The range and the variety of opinions indicate the plurality of political alternatives represented in the system. The balance of opinion means that all relevant social groups and political actors - and therefore opposing viewpoints - must have access to mass media (Schulz, 2000: 2). Two different structural principles are discussed in the literature as the basic patterns of content diversity: Internal content diversity can be guaranteed by any individual medium if it reflects the entire spectrum of existing political viewpoints. External content diversity is guaranteed by a plurality of media actors, each of them representing a particular political perspective. Although the latter model accepts that contents provided by individual media are imbalanced, it can be assumed that as long as there is a balance of politically aligned media actors at the aggregate level, media diversity is guaranteed (Voltmer, 2000: 10).

Equality as an evaluative principle also implies the criterion of media objectivity. This criterion also has other sources of support, such as the criterion of media independence (identified as a benefit of freedom). According to McQuail (1992: 73), the link with equality is strong as far as "objectivity requires a fair and non-discriminatory attitude to sources and to objects of news reporting - all should be treated on equal terms." Westerstahl (1983) demonstrates that objectivity is primarily a form of media practice and it expresses a particular attitude toward the task of information collection, processing, and dissemination (organizational goals and professional norms). Objectivity calls for compliance with truthfulness criteria like accuracy or relevance and it also covers aspects of balance (or non-partisanship) and neutral presentation.

Control, which calls for the media to play a watchdog role, interfaces and overlaps to a great extent with the benefits described under the headings 'freedom' and 'equality.' For example, the criterion of media independence is also a condition for exercising a watchdog function, i. e., through criticism and control of political and economic power. At the same time, diversity of media actors is essential insofar as vertical and 
diagonal concentration reduces mutual journalistic control (Schulz, 2000: 4). The central criterion that media must meet in order to carry out their watchdog role, however, is criticism. The most important structural condition required for the media in this context is the availability of sufficient resources to exercise the watchdog role: "The more money is at the disposal of a newspaper or radio station, the more news agencies can be subscribed to, the more reporters can be employed, the more money can be invested into forms of investigative journalism" (Schulz, 2000: 3). According to Norris (2000: 34), the most effective way to explore the extent to which the media provide effective scrutiny of government and big business is "[...] with historical case studies describing the role of the media in classic examples of the abuse of power, public scandals and government corruption [...]."

To sum up: The performance criteria and structural conditions discussed above reflect a summary of mainstream and widely found features underlying most media systems in contemporary democracies. There is an intrinsic connection and occasional tension between the features identified. To cite only a few examples: The main concepts of access and diversity appear under the headings of both 'freedom' and 'equality.' Objectivity, which is connected with the principle of 'equality,' has links with the principle of 'freedom,' as independence is a necessary condition for impartiality and truthfulness. Under certain extreme conditions (e. g., political repression, crisis, war, etc.), by contrast, the freedom to report can only be exercised in return for a guarantee of objectivity (McQuail, 1992: 73). Despite such overlapping, the main features discussed can be expressed as a set of several variables constituting our analytical framework. The variables refer, on the one hand, to structural conditions and, on the other, to performance criteria that the media must fulfill. Based on these findings, we can identify measurable indicators for thoroughly monitoring the mass media.

For the purpose of developing a monitoring instrument, we went one step further and deduced a number of indicators from these general principles. In order to keep the instrument workable, we decided to concentrate on the meso level, while including only a few micro aspects to the instrument. We justify the elimination of the macro level by the limited applicability of the instrument to mature democracies. Within these political settings, it can be assumed that basic communication rights are given and undisputed. The content level, at the other end of the spectrum, has been eliminated because of research economics and methodological difficulties. Content analysis would of course substantially add to the MDM and would provide additional insights; however, research capacity often allows only for a limited instrument and content analysis can easily be added as a complement when resources become available. 
Table 1. Democracy root concept for the Media for Democracy Monitor (MDM).

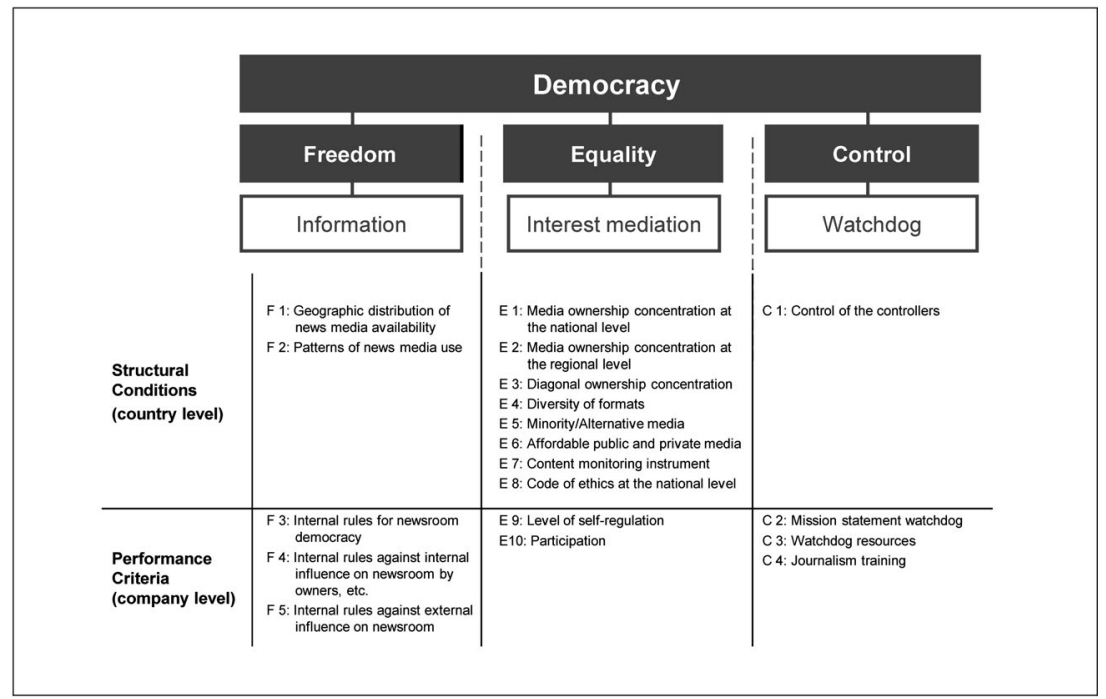

Table 1 illustrates our theory concept and contains 19 indicators that have been developed to provide a number of measurable areas for each democracy principle. Each indicator is defined and how each of these indicator criteria applies in the countries under review is also illustrated.

\section{Indicators}

For each dimension we defined relevant indicators to illustrate the performance of the media with regard to the respective democracy function. Each indicator should refer to the dimensions of freedom, equality, and control; data should be available to measure the degree to which the requirements are met. The following indicators have been developed:

\section{Freedom: 'Diversity of media supply/Media availability'}

This structural feature refers to the specific country and its media landscape. According to this feature, freedom is better guaranteed if the relevant news media are available to all citizens and widely used by them. The following two indicators deal with the distribution and consumption of news: 


\section{Indicator F1: Geographic distribution of news media availability}

Are the relevant news media available to all citizens? Is there a regional divide?

This indicator relates to the geographic distribution of news media. It seeks a media landscape which is characterized by high levels of public access, including for marginalized groups, and by the possibility of efficient use of technology to gather and distribute news and information. News media should therefore be widely available and regional divides should not exist. This implies a high degree of technical reach and unrestricted access to news media so that a full supply of all types of news media can be guaranteed. Geographic distribution as an indicator of freedom should not be undervalued. It has always been a key principle of media structure, closely connected with social structure: "Differences of geography may also coincide with ethnic, religious or language differences within the national society" (McQuail, 1992: 115).

Indicator F2: Patterns of news media use (consumption of news)

What is the distribution of media use between newspapers, television news, radio news, and online media? What is the reach of the main news broadcasts?

This indicator relates to the reach of the primarily used news media. It focuses on the daily usage share of newspapers, television, radio, and online media. Such a survey shows which news media reach the largest group of citizens and which media therefore have a potentially greater influence on public opinion.

\section{Freedom: Editorial and journalistic autonomy}

This performance feature refers to the selected news media and focuses on the status of editorial and journalistic autonomy within media organizations. It calls for the granting of a degree of independence from internal and external influences and pressures.

\section{Indicator F3: Internal rules for newsroom democracy}

Is there a formal procedure for involving journalists in decisions on personnel, editor-in-chief, etc.?

This indicator relates to the idea of newsroom democracy and to conditions of freedom for the editorial staff. It looks for organizational structures that guarantee the independence of the individual member of the editorial staff and thus the promotion of responsible and re- 
sponsive journalism (objective reporting). There can be different ways to ensure the internal freedom of the press and to involve journalists in the management of information and in important decisions at the heart of a media organization (existence of newsroom council, internal rules of electing/appointing the editor-in-chief, etc.). The indicator seeks to ascertain if any formal procedures (or strict rules) have been established to ensure journalists' participation in decision-making (e. g., via a newsroom council or through regular procedures for nominating the editor-in-chief).

Indicator F4: Company rules against internal influence on newsroom/ editorial staff

What is the degree of independence of the newsroom vis-à-vis the ownership/management? Are there rules on the separation of the newsroom from the ownership/management? Are they implemented?

This indicator relates to the degree of interference by the management and other internal controllers on editorial decisions. It assumes that democratic freedom is greater when more journalists can decide independently on editorial matters. The question does not of course arise in the same way when government has legitimate control over the media (as in most European public broadcasting systems) and sets legal limits to freedom (McQuail, 1992: 117). To safeguard the independence of newsrooms and journalists against the management or sales department, however, some internal rules are useful. An important rule, for instance, is that the newsroom and the management must be clearly separated. This prevents internal manipulation and influence as well as avoids involving the newsroom in advertising relationships.

Indicator F5: Company rules against external influence on newsroom/ editorial staff

What is the degree of interference by external parties (e.g., proprietors, advertisers, etc.)? Do news media receive revenue from a multitude of sources?

This indicator relates to the degree of interference by external parties on editorial decisions. These are influences that derive from pressures in the operating environment of the media, particularly from advertisers, news sources, and organized pressure groups or public relations bodies. In practice, media often rely on several different simultaneous sources of income - a condition that conventional wisdom holds to be better for freedom. Particularly in the case of the newspaper, we can say that the more financial resources originating from a third 
party (e.g., government, a single large advertiser or sponsor), the less plausible is the claim of full independence (McQuail, 1992: 106).

\section{Equality: Quantitative diversity}

This structural feature refers to the specific country and its media system. According to this feature, equality is better guaranteed if there are large numbers of different media outlets (quantitative external diversity). Ownership structure is accordingly regarded as the most crucial element. It is also equally important that the news should be able to reach the citizen by means of different formats. Finally, there is a greater chance of achieving equality if mass media are employed by minority groups (alternative media, third sector).

\section{Indicator E1: Media ownership concentration at the regional level}

What is the degree of ownership concentration at the regional level?

This indicator measures the degree of ownership concentration in the market of regional news media. In this context, each country must first define its major communication areas and then show the regional selection of newspapers, broadcasters, and online media. Ideally, more than two competing news media outlets are available in each news media sector. With a lower concentration, a larger number of 'players' has access to the market and the likelihood of the emergence of more diverse opinions is greater.

\section{Indicator E2: Media ownership concentration at the national level}

What is the degree of ownership concentration at the national level?

This indicator refers to the degree of ownership concentration at the national level. The central assumption is that concentration in the media may compromise the plurality of the media landscape. A national market controlled by one operator (monopoly) or by two (oligopoly) can be problematic in this regard. Ideally, more than two competing news media outlets should therefore be available in each news media sector.

\section{Indicator E3: Diagonal ownership concentration}

What is the degree of diagonal ownership concentration? Are relevant news media partly or fully owned by non-media companies?

This indicator refers to the degree of diagonal (or cross-media) ownership concentration. Diagonal concentration refers not only to one media market (like E1 and E2) and can be understood in two ways: First, 
it can be simple cross-ownership, such as when a newspaper owner holds a share in a television or radio station. It can also apply when a non-media company (e.g., from the pharmaceutical, steel, real estate, or private equity sector) acquires a stake in a mass medium.

\section{Indicator E4: Diversity of formats}

Is there diversity in news presentation formats?

This indicator measures the diversity of the respective formats and news presentations. It indicates plurality of information through multiple types of newspapers, broadcasters, and online media as well as their use to provide news to the public. Accordingly, it can be said that when more options and greater variety of news formats exist, there is thus more diversity that is then provided to the consumer. It is not plausible to assume that ownership diversity alone would automatically translate into news format diversity (see ownership concentration E1-3).

\section{Indicator E5: Minority/Alternative media}

Do minority/alternative media exist? Are all types of minorities served by media? Do they have their own media? Minorities include ethnic groups, those with disabilities, women, minority linguistic groups, etc.

This indicator refers to the existence of minority/alternative media. It is uncontested that media can contribute to diversity by reflecting differences in society: "Media are expected to represent the prevailing differences of culture, opinion and social conditions of the population as a whole" (McQuail, 1992: 144). Ideally, all major minorities of a country are served by a variety of special minority/alternative media or are well-represented by other media based on rules or conventions.

\section{Equality: Access diversity}

This structural feature refers to the specific country and its media system. According to this feature, equality is better guaranteed if there is a plurality of affordable public and private news media and thus more choices for citizens.

\section{Indicator E6: Affordable public and private news media}

What is the relative price of the mass media in relation to average household income?

According to this indicator, media should be available at a reasonable price. In order to provide people with equal opportunities to inform 
themselves on a regular basis, the price of the available media must be within the means of a majority of the population. This indicator measures the cost of access to newspapers (price of subscription), television and radio (license fee, pay TV), and online media (broadband connection).

\section{Equality: Content diversity}

This structural feature refers to the specific country and its mass media landscape. According to this feature, equality is better guaranteed if there is a large number of politically neutral outlets (internal diversity) or a balance of politically aligned media organizations at the aggregate level (external diversity). For this reason, it is important that there are bodies or institutions that can monitor, for example, the actual political neutrality of the media.

\section{Indicator E7: Content monitoring instrument}

Is there a regular and publicly available issue monitoring instrument for news media?

This indicator illustrates if a country's media system has a body or an instrument to monitor news media content. Such an instrument should be independent, publicly available, and able to operate on a regular basis. Such content monitoring might be institutionalized by the media themselves, by supervising bodies, by university institutes, or other organizations. The existence of a permanent content monitoring institution by itself is considered to have a positive impact on journalists' behavior and helps to foster the idea of media accountability.

\section{Equality: Objectivity}

Objectivity is both a performance and a structural feature. On the one side, it refers to the selected news media and the internal regulation of its organizations and, on the other side, it focuses on the countries' national regulations. According to this, the media should be able to guarantee both objective reporting and the existence of appropriate national measures (e. g., ethics codes).

\section{Indicator E8: Code of ethics at the national level}

Does a code of ethics at the national level exist which requires news media to provide fair, balanced, and impartial reporting? Is it known about and adhered to? 
This indicator examines the existence of a national code of ethics and its implementation and usage by media personnel. Moreover, it looks for institutions involved in handling complaints on media performance, such as journalist associations, complaint commissions, and ombudsmen.

\section{Indicator E9: Level of self-regulation}

Does a media self-regulation system exist for the main news media? Do these systems require fair, balanced, and impartial reporting? Are they effective?

This indicator seeks to determine the existence of an institutionalized and effective self-regulation system for the main news media of a country. It checks if internal tools for editorial policies (such as mission statements, codes of ethics, editorial guidelines, etc.) are implemented in line with formal rules. The central assumption is that the mass media, within a prevailing climate of self-regulation and respect for the journalistic profession, effectively reflect and represent the diversity of views and interests in society.

\section{Equality: Platform for democratic discourse}

This performance feature refers to the selected news media and monitors possibilities for people to participate in the news process. Participation promotes the reflection and representation of a diversity of views and interests in society.

\section{Indicator E10: Participation}

Is there an organized way for people to participate in the news process?

This indicator examines the extent to which news media give citizens the opportunity to voice their own views and reactions to news stories they read or hear. Moreover, it looks at how well the media encourage citizens to even participate in the production of news. Such an approach asks the news media to be open to forms of cooperation with citizens. Lastly, it can be said that the larger the number of citizens who participate, the greater the chance of having a multitude of opinions. Online media are best situated to organize such a forum by providing web-space for user reactions. 


\section{Control: Public criticism}

This structural feature refers to the specific country and its media system. It focuses on control mechanisms that exercise a watchdog role with regard to the media itself.

\section{Indicator C1: Supervising the watchdog / 'control of the controllers'}

Is there any institutionalized mechanism to monitor the performance and role of the news media?

This indicator examines the existence of instruments to monitor media performance. It is important to examine what tools the different media have in order to adequately function as a watchdog as well as to look at how far the media actually deal with controversial matters, engage in public criticism, and risk antagonizing either powerful interests or their own audience. Moreover, it is important to examine the degree to which the media play an active role in their society or community.

\section{Control: Journalistic accountability}

This performance feature refers to the selected news media. The focus is on mechanisms which encourage journalistic accountability and promote democratic control of the government and big business.

\section{Indicator C2: The watchdog and the media's mission statement}

Does the mission statement of the company or the newsroom contain provisions on playing an active watchdog role, on investigative journalism, or on other forms of power monitoring?

This indicator examines extent to which the news media perform their mission as watchdogs. The view of media as a watchdog against the abuse of power and corruption has long been a staple ingredient of the journalistic self-image and of Western democratic political theory (McQuail, 1992: 120). This indicator intends to reveal how far the watchdog function is perceived as important both in theory and in practice. Furthermore, it seeks to uncover whether a mission statement exists that refers explicitly to active investigative journalism.

\section{Indicator C3: Professional training}

How much importance is attached to journalism training?

This indicator provides information on whether journalists are given the chance to take part in professional training courses. The news media can only perform their watchdog duty if they have qualified 
personnel resources. In order to do so, the news media should provide their staff with training courses in watchdog journalism.

\section{Control: Resources}

This performance feature refers to the selected news media. The basic condition for exercising the watchdog role is that sufficient resources are available for journalists in the newsrooms. The more money there is at the disposal of newsrooms, the greater the number of news agencies that can be subscribed to, the more reporters who can be employed, and the more funds that can be invested into forms of investigative journalism, etc. (Schulz, 2000: 3).

\section{Indicator C4: Watchdog function and financial resources}

Are there specific and sufficient resources for exercising investigative journalism or other forms of power monitoring?

This indicator refers to the financial resources of newsrooms for performing their watchdog function. To perform their mission as a watchdog in an appropriate way, it is crucial that they have the appropriate means with respect to time and budgets. Limited resources have often been cited as a potential cause of constraint on the independence of journalism. Resources for their own investigations reduce the dependency on agency material. Additionally, news media perform better if they can make use of journalists who are specialists on given subjects. In this way, there will be more room for investigative journalism.

\section{Empirical research concept}

The Media for Democracy Monitor is designed as a multi-annual comparative instrument and is open to include established (or: advanced, mature, contemporary) democracies. The methodology of the monitoring instrument is designed to conform to three key characteristics:

- Simple: The instrument is largely based on qualitative data collected by experts in various countries. There is an important normative element in the instrument, and the results depend, to some extent, on the professional perception of the country expert. Although social science methods are applied, there remains some subjectivity in evaluating the country's media system with regard to democracy. Therefore, the instrument cannot be based on sophisticated statistical methods; it should rather reflect the performance of the leading news media. The instrument is designed in this regard to be simple. 
- Comparative: The instrument must be applicable to a large variety of countries. Although restricted to so-called advanced or mature democracies, the variety of democracy models is great. A highly sophisticated monitoring instrument would necessarily take national specificities into account - at the expense of the comparative approach. We therefore chose methods (and questions) applicable to all such democracies without going into detail with regard to specific democratic features that might apply in one country but not in others. The instrument is designed to be comparative.

- Transparent: From a social science perspective, the most important requirement on such an instrument is transparency. The monitoring instrument justifies the choice of indicators (basically with reference to literature) as well as the "democracy points" given. National correspondents deliver detailed accounts about their countries, with this information being an integral part of the overall report. Readers may go back to each indicator to review the information provided by the country experts. The instrument thus delivers a high level of transparency.

\section{Objects of investigation}

Choice of countries. The 19 indicators have already been applied in 2008 in a pilot study covering a number of countries. The choice of the countries was limited by the research budget that allowed for no more than five. The choice was also influenced by the availability of researchers willing to volunteer for the pilot study. Despite these constraints, we sought to select countries that are as different from each other as possible, namely, Germany, Lithuania, the Netherlands, Portugal, and Switzerland. These countries differ in various respects:

- On the large-small continuum (e. g., Germany and Switzerland);

- On the north-south continuum (e.g., Lithuania and Portugal);

- On the east-west continuum (e. g., Netherlands and Lithuania);

- On the old-new democracy continuum (e. g., Lithuania and the others).

In each country, a small team of social scientists were chosen to deliver a report on all indicators. A short version of these extensive country reports is documented in the annex ${ }^{4}$.

Choice of leading news media. The indicators were extensively discussed in a joint workshop in November 2007. In order to apply the instrument in the selected country, each researcher made a comprehensive selection that reflected a representative picture of the pertinent media system (me- 
dia sample). As the media landscape is becoming more diverse and as media consumption habits are changing, the sample had to include different media types that can be broken down into four main sectors:

- Newspapers;

- Television news;

- Radio news;

- Online news.

The content produced by each media sector varies considerably in quantity, as do audience sizes. In order to be representative, the sample has to meet further criteria, such as the inclusion of the main elite media (media of the "governing") as well as the main citizen media (media of the "governed"). The latter corresponds to the media with the highest audience reach (amount of reach/circulation). The elite media, on the other hand, refer to the leading quality news media.

\section{Method}

In order to apply the 19 indicators in practice, they had to be more narrowly defined. First, we formulated a precise question for each indicator. Moreover, we had to define the main requirement explaining why the indicator is relevant for assessing whether the media promote democracy. In a further step we defined appropriate criteria allowing us to assess whether the question relating to the indicator can be answered positively or negatively. Depending on whether these criteria are fulfilled or not, we attributed 'democracy points' between 0 and 3 measuring the extent to which the media meet the expectations set out in the indicator:

$-0=$ Country's news media do not meet any criteria of the indicator;

-1 = Country's news media meet some criteria of the indicator;

$-2=$ Country's news media meet most criteria of the indicator;

-3 = Country's news media meet all criteria of the indicator.

Finally, we decided on the data sources that provided us with the necessary information for each indicator. The data for the study were generally collected in two parts. The first consists of existing statistical data and data originated by other researchers that were collected and aggregated (through desk research). The second part is original primary research consisting of interviews conducted with media professionals of the leading news media. For this purpose a non-standardized questionnaire was developed with the formulated questions referring to specific indicators. All leading interviews were conducted personally. Table 2 
Table 2. Closer definition of indicators F3, E1, and C2 (examples).

(F3) Internal rules for newsroom democracy

\begin{tabular}{ll}
\hline Question & $\begin{array}{l}\text { Is there a formal procedure on how to involve journalists in } \\
\text { decisions on personnel, editor-in-chief, etc.? }\end{array}$ \\
Requirement & $\begin{array}{l}\text { If effective rules in this regard exist, it is more likely that } \\
\text { democratic freedom is guaranteed and thus that democracy is } \\
\text { promoted. }\end{array}$ \\
Points & 3 Full democratic control by journalists in the newsrooms \\
& 0 Decisions in the newsroom do not involve journalists at all \\
Criteria & - Existence of a newsroom council \\
& - Internal rules for electing/appointing editor-in-chief, other \\
& - positions, etc. \\
& - Journalists choose their editor-in-chief
\end{tabular}

Data Sources Interviews

(E1) Media ownership concentration at the regional level

\begin{tabular}{ll}
\hline Question & What is the degree of ownership concentration at the regional \\
level? & The lower the regional ownership concentration, the more \\
democratic equality is guaranteed and the higher the potential that & democracy is promoted. \\
& 3 More than two competitors in all regions for all news media \\
types (newspapers, TV, radio, etc.)
\end{tabular}

Date Sources Statistics (data, calculated market share 'CR3' of main regions in the country)

(C2) The watchdog and the media's mission statement

\begin{tabular}{ll}
\hline Question & $\begin{array}{l}\text { Does the mission statement of the company or the newsroom } \\
\text { contain provisions on playing an active watchdog role/on } \\
\text { investigative journalism or other forms of power monitoring? }\end{array}$ \\
Requirement & $\begin{array}{l}\text { If a mission statement concerning watchdog journalism exists, it is } \\
\text { more likely that democratic control is guaranteed and that } \\
\text { democracy is promoted. }\end{array}$ \\
Points & 3 All relevant news media refer to watchdog role and exercise it
\end{tabular}


Table 2. (continued)

\begin{tabular}{ll}
\hline & No watchdog role is played \\
Criteria & - Existence of a mission statement that refers to active \\
& investigative journalism and duties to act as a trustee on behalf \\
& of the public \\
- & Level of importance of the watchdog role for the media \\
& organization \\
- & Examples of accountable watchdog role \\
- & $\ldots$
\end{tabular}

Data Sources Interviews

shows the closer definition of three example indicators and displays the criteria the research team applied for each one. The empirical findings from the project interlocutors in the five countries involved are documented for these three example indicators in the annex.

\section{Findings}

The first comparative pilot study applying the MDM to Germany, Lithuania, the Netherlands, Portugal, and Switzerland has been successfully carried out. The final analysis reveals some interesting results, which are common to all the countries covered:

- Although mass media are essential for contemporary democracies, the level of internal democracy within news media organizations is low. Even highly reputable mass media are not always organized internally as democratic institutions. There seems to be a gap between the democratic role for the public and the media's own internal democracy.

- Some of the most popular mass media have only low-profile institutional protection of newsroom independence. The separation of newsrooms from the management seems to erode significantly in media entirely financed by advertising.

- Mass media that best serve democracy invest in quality journalism and provide the necessary resources for investigative and responsible reporting. Some of the most popular mass media appear to cut back on these expenses. Journalism in some of these media organizations is restricted to re-writing and editing of wire service reports with no or little own investigation.

The following table provides an overview of the findings for each indicator and each country. It also shows the democracy points given for each 
Table 3. Pilot study findings - overview.

'Democracy Points'

per Indicator, Dimension, and Country

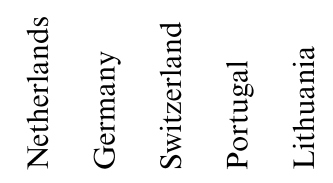

\begin{tabular}{|c|c|c|c|c|c|c|c|}
\hline \multirow{6}{*}{ 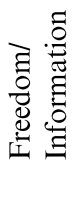 } & F1 & Geographic distribution of news media & 3 & 3 & 3 & 3 & 3 \\
\hline & $\mathrm{F} 2$ & Patterns of news media use (consumption) & 3 & 3 & 3 & 2 & 1 \\
\hline & F3 & Internal rules for newsroom democracy & 3 & 1 & 0 & 2 & 1 \\
\hline & F4 & Company rules against internal influence & 2 & 2 & 2 & 2 & 1 \\
\hline & F5 & Company rules against external influence & 2 & 2 & 2 & 1 & 0 \\
\hline & & Total Freedom/Information $(\max .=15)$ & 13 & 11 & 10 & 10 & 6 \\
\hline
\end{tabular}

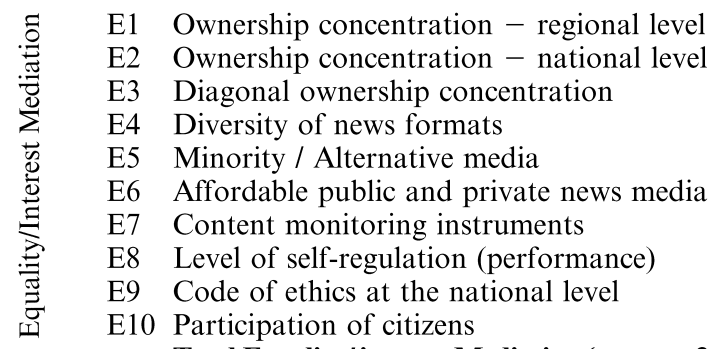

Total Equality/interest Mediation $(\max .=30)$

\begin{tabular}{|c|c|c|c|c|c|c|c|}
\hline \multirow{5}{*}{ 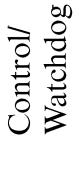 } & $\mathrm{C} 1$ & Control of the controllers & 2 & 2 & 2 & 2 & 1 \\
\hline & $\mathrm{C} 2$ & Watchdog and the media's mission statements & 3 & 1 & 2 & 1 & 1 \\
\hline & $\mathrm{C} 3$ & Professional training & 2 & 2 & 2 & & \\
\hline & $\mathrm{C} 4$ & Watchdog function and financial resources & 1 & 3 & 2 & 1 & \\
\hline & & Total Control/Watchdog $(\max .=12)$ & 8 & 8 & 8 & 5 & 5 \\
\hline & & Total MDM Points $(\max .=57)$ & & 43 & 39 & 35 & 29 \\
\hline
\end{tabular}

indicator by the research team based on the information provided by the national correspondent. The complete version of the final research report includes a comprehensive version of each country report and is made available by the research team (Trappel and Maniglio, 2009).

According to these findings, the leading news media in the Netherlands are best equipped among the five countries reviewed to support democracy. These media scored particularly high in the freedom and equality dimensions. This reflects the high level of awareness about media matters in the Netherlands and the high level of observation to which mass media there are subjected. Regarding the media's watchdog function, the media studied prove to perform adequately, although newsrooms and journalists were often given fewer resources to fulfilling their watchdog function in recent years. 
In contrast, at the other end of the list, Lithuania scores lowest with 29 democracy points. A general trend is observed that the media, mainly driven by consumerist approaches, have gradually abandoned the public service mission of journalism. The Lithuanian media system has so far developed only marginal internal mechanisms for quality control; the influence of powerful institutions is comparably high and resources are insufficient for the mass media to perform effectively as watchdogs.

Germany, Portugal, and Switzerland rank in between. Germany's high scores reflect the country's available resources to sustain critical journalism. Germany scored well in the control dimension, indicating that Germany's leading news media perform well as watchdogs. Switzerland has relatively low scores in the freedom/information dimension. This is partly due to the minimal influence journalists have in newsroom democracy and partly due to the relatively low level of protection against internal and external influence on the newsrooms. Nonetheless, Swiss media perform well as watchdogs because the necessary resources are available and a strong public service organization keeps the level of professional standards high. Portugal, finally, has low scores in the equality/ interest mediation dimension. Mass media consumption is relatively expensive in Portugal and the level of self-regulation is low. As most media are struggling with the economic recession, resources for watchdog and investigative reporting are limited.

The following table helps to better compare these findings. On the one hand, it shows the percentage of the highest possible score per dimension and country; and, on the other, it adds up the three respective dimension values and determines their total averages.

Table 4. Findings per dimension.

\begin{tabular}{llllll}
\hline $\begin{array}{l}\text { Percentage of the Maximum Score } \\
\text { per Dimension and Country }\end{array}$ & $\begin{array}{l}\text { Nether- } \\
\text { lands }\end{array}$ & Germany & $\begin{array}{l}\text { Switzer- } \\
\text { land }\end{array}$ & Portugal Lithua- \\
nia
\end{tabular}

\section{Conclusions}

The mass communication field is rich in research concerning the importance of the mass media for democracy but knows surprisingly little 
about their democracy-related performance. Systematic observations and monitoring are rare and the constant changes in the media environment do not make them easier to carry out. Although the number of existing media monitoring institutions is large and growing, the instruments used by them are generally too simple to measure media's contribution to the functioning of democracy. There is thus an inevitable need for a monitoring instrument that measures media performance in a more accurate way - as is allowed by the "Media for Democracy Monitor (MDM)." However, the analytical instrument developed and presented in this report is by no means final. It certainly must be refined and deepened in order to do justice to the complex realities of democracy and media (e.g., developing new indicators, finding solutions for the statistical or theoretical allocations, etc.).

The main challenge of the research project was the choice of relevant indicators. In a joint country workshop in November 2007, the indicators were discussed in detail. The pilot study applying the MDM to the five European countries (Germany, Lithuania, the Netherlands, Portugal, and Switzerland) showed clearly that our indicators can be operationalized in different countries. The quantitative media market data as well as the qualitative data collection were comparable in most cases.

In order to make the instrument workable, we decided to concentrate on the meso level, while considering only a few aspects at the micro level (e. g., the output of the media). We were therefore unable to focus attention on the macro level, which is the level of legal and administrative rules and regulations. Accordingly, most of the selected 19 indicators relate to media organizations, their newsrooms, and to journalistic conduct. One of the most interesting findings in this regard was indeed the gap between the importance of the role of the mass media in democracies and the low level of internal institutional provisions to safeguard internal democracy as well as the dearth of arrangements to safeguard high quality standards for journalism in the leading mass media. The focus on internal democracy was as such unproblematic, as we focused only on mature democracies. In mature democracies it can be assumed that more or less appropriate legal and administrative rules and regulation exist. However, the limitation on the meso level might be too narrow to respond to our crucial question concerning the requirements media must meet in order to promote democracy. Without a doubt, our initial findings contribute to the continuous debate on the role of the media for democracy at an elevated level. Increased commercialization and the refusal of some mass media to accept their democratic responsibility are issues that are discussed frequently as media policy decisions are being made (renewal of licenses, revisions of media law, role of the European policy on national media, etc.). In any case, it seems to be necessary 
to optimize the instrument and invest more time in considering further indicators, theories, and methods. This is all the more important as the MDM Project has the potential to make a substantial contribution to the body of evidence in the research field of political communication. It is therefore planned to continue the project and regularly produce a comparative annual or bi-annual media performance monitor.

It is important to continue efforts to analyze the media's contribution to democracy because only by specifying democracies' normative implications for media as well as by identifying indicators by which the quality of news media might be evaluated, can we fully understand how media affect democracy. It should thus never be taken for granted that media promote democracy per se. As both democracies and media change over time, their (inter-)relationship must be constantly redefined and challenged.

\section{Bionotes}

Josef Trappel is Visiting Professor at the University of Vienna, Austria and Lecturer at the Institute of Mass Communication and Media Research, University of Zurich, Andreasstrasse 15, CH-8050 Zürich, Switzerland.

Tanja Maniglio is Research Assistant at the Institute of Mass Communication and Media Research, University of Zurich, Andreasstrasse 15, CH-8050 Zürich, Switzerland.

\section{Notes}

1. To these three models one should add what might be called 'procedural democracy' (Strömbäck, 2005). 'Procedural democracy' refers to Dahl's 'concept of polyarchy' (1971). The core idea of such minimalist concepts is that they contain all the basic requirements a polity must fulfill in order to be democratic. However, these concepts are based on such an extremely minimalist view of democracy that we cannot consider them as 'realistic' (Strömbäck, 2005: 334). We will therefore take this perspective into consideration but will not review it in detail.

2. This classification is taken from Bühlmann, Merkel and Wessels (2007).

3. This classification is taken from Bühlmann, Merkel and Wessels (2007).

4. The country experts are: André Donk, Frank Marcinkowski (Germany), Leen d'Haenens (Netherlands), Aukse Balčytienè, Egle Napryte (Lithuania), Joaquim Fidalgo (Portugal), Tanja Maniglio, Josef Trappel (Switzerland).

\section{References}

Baker, C. E. (2006). Journalist Performance, Media Policy, and Democracy. In F. Marcinkowski, W. A. Meier, and Trappel, J. (Eds.), Media and democracy. Experiences from Europe (pp. 115-126). Berne: Haupt. 
Becker, L. B., Vlad, T., and Nusser, N. (2007). An evaluation of press freedom indicators. International Communication Gazette, 69, 5-28.

Bruck, P. A. and Raboy, M. (1989). The challenge of democratic communication. In P. A. Bruck. and M. Raboy (Eds.), Communication for and against Democracy (pp. 3-16). Montréal: Black Rose.

Bühlmann, M., Merkel, W., and Wessels, B. (2007). Quality of democracy: Democracy barometer for established democracies. Zurich, Berlin. Working Paper of the NCCR-Democracy, No. 10. Retrieved October 30, 2007, from http://www. nccr-democracy.uzh.ch/nccr/publications/workingpaper/pdf/WP10.pdf

Curran, J. (2000). Rethinking media and democracy. In J. Curran and M. Gurevitch (Eds.), Mass media and society ( ${ }^{\text {rd }}$ ed., pp. 120-154). London: Arnold.

Dahl, R. A. (2006). On political equality. New Haven, London: Yale University Press.

Dahlgren, P. (2001). The public sphere and the Net: Structure, space, and communication. In W. L. Bennett and R. M. Entman, (Eds.), Mediated politics. Communication in the future of democracy (pp. 33-55). Cambridge: Cambridge University Press.

Deutsch Karlekar, K. (2006). Press freedom in 2005. Retrieved June 29, 2007 from http://www.freedomhouse.org/template.cfm?page $=131 \&$ year $=2006 \&$ essay $=26$

Diamond, L. and Morlino, L. (2004). The quality of democracy. Stanford. Working Paper of the Center on Democracy, Development, and the Rule of Law (CDDRL). Stanford Institute on International Studies, No. 20. Retrieved October 30, 2007 from http://iis-db.stanford.edu/pubs/20729/Diamond-Morlino.QoD. intro(book).drft1.pdf

Elster, J. (1998). Deliberative democracy. New York: Cambridge University Press.

Fenske, H., Mertens D., Reinhard W., and Rosen, K. (1994). Geschichte der politischen Ideen: Von Homer bis zur Gegenwart. Frankfurt a. M.: Fischer.

Gutmann, A. and Thomson, D. (1996). Democracy and Disagreement: Why moral conflict cannot be avoided in politics, and what should be done about it. Harvard: Belknap.

Habermas, J. (1992). Drei normative Modelle der Demokratie: Zum Begriff deliberativer Demokratie. In H. Münkler (Ed.), Die Chancen der Freiheit. Grundprobleme der Demokratie (pp. 11-24). Munich, Zurich: Piper. [Reprinted in: Habermas, J. (1996). Die Einbeziehung des Anderen. Frankfurt a. M.: Suhrkamp, pp. 277292.].

Hallin, D. C. and Mancini, P. (2004). Comparing media systems: Three models of media and politics. Cambridge: Cambridge University Press.

Held, D. (2006). Models of democracy ( $3^{\text {rd }}$ ed.). Cambridge: Polity Press.

Hutchins Commission (1947). A free And responsible press. Chicago: University of Chicago Press.

Kelley, D. and Donway, R. (1990). Liberalism and free speech. In J. Lichtenstein (Ed.), Democracy and the mass media (pp. 66-110). Cambridge: Cambridge University Press.

Lauth, H.-J. (2004). Demokratie und Demokratiemessung: Eine konzeptionelle Grundlage für den interkulturellen Vergleich. Wiesbaden: VS.

McQuail, D. (1992). Media performance: Mass communication and the public interest. London: Sage Publications.

McQuail, D. (1999). On evaluating media performance in the public interest: Past and future of the research tradition. In K. Nordenstreng and M. Griffin (Eds.), International media monitoring (pp. 25-38). Cresskill, NJ: Hampton Press.

McQuail, D. (1994). Mass ccommunication theory ( $3^{\text {rd }}$ ed.). London: Sage.

McQuail, D. (2005). Mass communication theory (5 $5^{\text {th }}$ ed.). London: Sage.

McQuail, D., and Siune, K. (Eds.). (1998). Media policy: Convergence, concentration and commerce. London: Sage. 
Merritt, D. (1998). Public journalism and public life - Why telling the news is not enough. Hillsdale, NJ: Lawrence Erlbaum Associates.

Nerone, J. C. (1995). Last rights: Revisiting four theories of the press. Urbana: University of Illinois Press.

Nordensteng, K. (2001). Media and democracy: Do we know what to do? Television and New Media, 2, 57-63.

Nordenstreng, K. (2006). 'Four Theories of the Press' reconsidered. In N. Carpentier, P. Pruulmann-Vengerfeldt, K. Nordenstreng, M. Hartmann, P. Vihalemm, and B. Cammaerts (Eds.), Researching media, democracy and participation: The intellectual work of the 2006 European Media and Communication Doctoral Summer School (pp. 35-45). Tartu: Tartu University Press.

Norris, P. (2000). A virtuous circle: Political communications in postindustrial societies. Cambridge: Cambridge University Press.

PEJ (2007). About us. Retrieved July 24, 2007 from http://www.journalism.org/about_ pej/about_us

Picard, R. G. (1985). The press and the decline of democracy: The democratic socialist response in public policy. Westport, CT: Greenwood Press.

Raboy, M., and Bruck, P. A. (Eds.). (1989). Communication for and against democracy. Montreal: Black Rose Books.

Sarcinelli, Ulrich (1995). Kommunikationstheorien der Politik. In D. Nohlen and R.-O. Schulze (Eds.), Politische Theorien: Lexikon der Politik (Vol. 1, pp. 241248). Munich: Beck.

Schudson, M. (1996). The power of news. Cambridge, MA, London: Harvard University Press.

Schudson, M. (2003). The sociology of news. New York: Norton.

Schmidt, M. G. (2000). Demokratietheorien. Opladen: Leske and Budrich.

Schulz, W. (2000, October). Preconditions of journalistic quality in an open society. Paper presented at the International Conference News Media and Politics - Independent Journalism, Budapest.

Siebert, F., Peterson, T., and Schramm, W. (1956). Four theories of the press: The authoritarian, libertarian, social responsibility and soviet communist concepts of what the press should be and do. Urbana: University of Illinois Press.

Strömbäck, J. (2005). In search of a standard: Four models of democracy and their normative implications for journalism. Journalism Studies, 6(3), 331-345.

Trappel, J., and Maniglio, T. (2009). Media for Democracy Monitor. NCCR Research Report. Zurich.

Voltmer, K. (1999). Medienqualität und Demokratie: Eine empirische Analyse publizistischer Informations- und Orientierungsleistungen in der Wahlkampfkommunikation. Baden-Baden: Nomos Universitätsschriften, Politik.

Voltmer, K. (2000). Structure of diversity of press and broadcasting systems: The institutional context of public communications in western democracies. WZB Discussion Paper FS III 00-201, Berlin.

Webster, F. (1999). Knowledgeability and democracy in an information age. Annual Ameritech Information Society Lecture. Edinburgh: Merchiston Publishing.

Westerstahl, J. (1983). Objective news reporting: General premises. Communication Research, 10(3), 403-424.

Whitehouse, M. (2006). Measuring change in media systems: The media sustainability index. In M. Harvey (Ed.), Perspectives on advancing governance and development from the global forum for media development (pp. 76-80). Beijing. 